\title{
Cold-Dependent Activation of Complement: Recognition, Assessment, and Mechanism
}

\author{
KENNETH P. MATHEWS, ${ }^{1,4}$ ROBERT A. MENTYKA ${ }^{3}$ SANDRA L. CHAMBERS, ${ }^{1}$ TONY E. \\ HUGLI, ${ }^{2}$ JACK H. HERSCHBACH, ${ }^{1}$ and BRUCE L. ZURAW ${ }^{1}$
}

Accepted: May 7, 1992

Cold-dependent activation of complement (CDAC) is a phenomenon characterized by low hemolytic complement activity in chilled serum. Complement component levels are normal when measured immunologically, and there is normal hemolytic activity in EDTA plasma or serum maintained at $37^{\circ} \mathrm{C}$. Little attention has been paid to CDAC except in Japan, and current unfamiliarity with it, even by clinical immunologists, can lead to confusion and unnecessary laboratory tests. A 66-year-old patient with a complex medical history is described whose complement tests showed abnormalities characteristic of CDAC. Evidence for classical complement pathway activation in the cold was obtained by $\mathrm{CH}_{50}$ measurements, by hemolytic $\mathrm{C} 4$ determinations, by $\mathrm{C} 4 \mathrm{a}, \mathrm{C} 3 \mathrm{a}$, and $\mathrm{C} 4 \mathrm{~d}$ generation, and by quantitating $\mathrm{C} 1 \bar{s}-\mathrm{Cl} \hat{\mathrm{r}}-(\mathrm{Cl} \text { inhibitor })_{2}$ complexes. A good correlation was observed among these parameters. Cryoprecipitates were absent. CDAC activity has persisted for over 5 years and is greater at 13 than at $4^{\circ} \mathrm{C}$. Activation is ablated by heating at $56^{\circ} \mathrm{C}$ and restored by the addition of $\mathrm{C} 1$ to the heated serum. Adsorption by streptococcal protein G-Sepharose and precipitation by $2.5 \%$ polyethylene glycol support the hypothesis that $\mathrm{CDAC}$ is caused by aggregated $\operatorname{IgG}$. The CDAC factor(s) also induces complement activation in normal serum but has not interfered with Raji cell or Clq binding tests or with FACS analysis. More limited studies of a second individual experiencing $\mathrm{CDAC}$ yielded similar results.

KEY WORDS: Complement; cryoproteins; IgG; anaphylatoxins; $\mathrm{Cl}$ inhibitor.

\footnotetext{
${ }^{1}$ Department of Molecular and Experimental Medicine, SRB-6, The Scripps Research Institute, La Jolla, California 92037.

${ }^{2}$ Department of Immunology, The Scripps Research Institute, La Jolla, California 92037.

${ }^{3}$ Division of Allergy, Department of Internal Medicine, University of Michigan, Ann Arbor, Michigan 48109.

${ }^{4}$ To whom correspondence should be addressed.
}

\section{INTRODUCTION}

Discrepancies between hemolytic complement activity in serum versus plasma have been reported in abstracts published beginning in 1970 (1-4). Although the initial emphasis was on the possible role of blood coagulation factors $(1-3,5)$, it was subsequently discovered that the serum abnormality was associated with cooling the serum in vitro $(4,6-14)$. The usual features of cold-dependent activation of complement (CDAC) include low $\mathrm{CH}_{50}$, low hemolytic $\mathrm{C} 4$, and normal hemolytic $\mathrm{C} 5-\mathrm{C} 9$ in chilled serum, whereas these values are nearly normal in EDTA plasma and in serum kept at $37^{\circ} \mathrm{C}$. In addition, immunologic measurements of complement components are normal even in chilled serum. $\mathrm{Cl}$ inhibitor ( $\mathrm{Cl} \mathrm{INH})$ levels also are normal, and precipitating cryoglobulins and cryofibrinogens are absent. Although there have been unreported cases, apparently only 11 patients with CDAC have been reported in the United States $(1-4,10)$. In contrast, more than 40 such individuals have been described by Japanese investigators (5-9, 11-13). Many of these patients had chronic liver disease, and 5 of 574 patients with primary renal disease had CDAC (9). In addition, Akasaki et al. (9) found evidence of CDAC in 5 of 8100 apparently healthy Japanese.

\section{CASE REPORTS}

\section{Patient 1}

Patient 1 was a 66-year-old woman who was initially seen by us in 1985 because of swelling and burning of the tongue. The complex medical history included hyperparathyroidism with resection of a parathyroid adenoma, thyroid nodule resection, splenectomy for splenic artery aneurysm, border- 
Table I. Initial Complement Measurements on Sera of Patients 1 and $2^{a}$

\begin{tabular}{|c|c|c|c|c|}
\hline & Patient 1 & Normal & Patient 2 & Normal $^{b}$ \\
\hline $\begin{array}{l}\mathrm{CH}_{50} \\
\mathrm{C} 1 \mathrm{q}\end{array}$ & $\begin{array}{l}<22 \mathrm{u} \\
24.3 \mathrm{mg} / \mathrm{dl} l\end{array}$ & $\begin{array}{c}104-188 \\
14-20\end{array}$ & 0 & 64 \\
\hline $\mathrm{C} 3$ & $153 \mathrm{mg} / \mathrm{dl}$ & $80-231$ & $86 \mathrm{mg} / \mathrm{dl}$ & $80-231$ \\
\hline $\mathrm{C4}$ & $25 \mathrm{mg} / \mathrm{dl}$ & $10-46$ & $20 \mathrm{mg} / \mathrm{dl}$ & $10-46$ \\
\hline $\mathrm{C} 1 \mathrm{INH}$ & $15.5 \mathrm{mg} / \mathrm{dl}$ & $11-23$ & & \\
\hline Functional $\mathrm{C} 1 \mathrm{INH}$ & 51,200 & 51,000 & 12,800 & 12,800 \\
\hline \multicolumn{5}{|c|}{ Hemolytic complement titers } \\
\hline $\mathrm{C} 1$ & 32,000 & 256,000 & 32,000 & 64,000 \\
\hline $\mathrm{C} 2$ & 12,500 & 12,800 & 1,200 & 6,400 \\
\hline C3 & 64,000 & 96,000 & 4,800 & 6,400 \\
\hline $\mathrm{C} 4$ & 0 & 64,000 & 24 & 24,000 \\
\hline $\mathrm{Cs}$ & 96,000 & 192,000 & 96,000 & 64,000 \\
\hline $\mathrm{C} 6$ & 128,000 & 128,000 & 64,000 & 64,000 \\
\hline C7 & 128,000 & 128,000 & 64,000 & 64,000 \\
\hline $\mathrm{C} 8$ & 64,000 & 128,000 & 48,000 & 48,000 \\
\hline $\mathrm{C} 9$ & 16,000 & 16,000 & 24,000 & 16,000 \\
\hline
\end{tabular}

${ }^{a}$ Tests performed elsewhere before being evaluated by us.

${ }^{b}$ Normal functional serum titers can vary on different days.

line polycythemia, a previous (but unsubstantiated) diagnosis of von Willebrand's disease, glaucoma, and hypertension. Aside from multiple surgical scars, the physical examination was unremarkable; the tongue appeared normal at that time.

Considering hereditary angioedema as a possible cause of the tongue swelling, a gastroenterologist had obtained $\mathrm{C} 3$ and $\mathrm{C} 4$ levels and a $\mathrm{CH}_{50}$. The former were normal, but the $\mathrm{CH}_{50}$ was immeasurably low. These tests were repeated together with other measurements noted in Table I. The most striking result was the absence of measurable hemolytic $\mathrm{C} 4$ activity in the presence of a normal $\mathrm{C} 4$ level as measured immunologically. Subsequent tests showed similar results except that hemolytic C2 was only one-fourth of control levels.

The following additional abnormalities have been noted: WBC of 13,500 , with $63 \%$ lymphocytes and increased platelets; Hgb, Hct, RBC, red cell mass, and total blood volume indicative of mild polycythemia; serum protein electrophoresis showing a polyclonal increase in $\gamma$-globulins; IgG elevated to $1750 \mathrm{mg} / \mathrm{dl}$ and $I g A$ elevated to $524 \mathrm{mg} / \mathrm{dl}$, with a normal IgM and IgE; IgG subclass measurements showing only IgG1 to be increased; $\mathrm{C} 3 \mathrm{~b}$ increased on immunofixation but normal alternative pathway activation following inulin stimulation; $\mathrm{Clq}$ binding of $14 \%$ (borderline, 13-16\%); a Raji cell test of 254 $\mu \mathrm{g}$ AHG Eq/ml (normal, <50); and a rheumatoid factor titer of 1:20 in chilled serum and negative at $1: 20$ in $37^{\circ} \mathrm{C}$ serum.

The most relevant normal or negative tests were the urinalysis, erythrocyte sedimentation rate (3 $\mathrm{mm} / \mathrm{hr}$ ), C-reactive protein, antinuclear antibody, anti-DNA, hepatitis $B$ antigens and antibodies, virus antibody screen, and cold agglutinins. In three tests there was an absence of cryoglobulin, cryofibrinogen, or heparin-precipitable cryoprotein after 7 days' observation and no decrease in $\mathrm{C} 4$ binding protein. Alpha-1 protease inhibitor and antithrombin III levels were normal. Tests for antimitochondrial, anti-smooth muscle, anti-parietal cell, anti-thyroglobulin, and anti-microsomal antibodies have been negative, as well as tests for von Willebrand's disease and coagulation abnormalities. Most liver function tests were normal. Subsequently a diagnosis of probable lymphocytic leukemia has been made based on persisting lymphocytosis and $5 \%$ of cells in the bone marrow appearing to be lymphoblasts. Flow cytometry in 1986 showed a $T$ cell lymphocytosis with atypical surface phenotype. The patient has not experienced significant adverse symptoms on exposure to cold.

\section{Patient 2}

Patient 2, a 27-year-old married female, had fortuitously been found in 1984 to have an immeasurably low $\mathrm{CH}_{50}$ level on three occasions when she served as a control for complement tests. Her antinuclear antibody test had been positive at a dilution of 1:320 (homogeneous pattern), she had been experiencing Raynaud's phenomenon for about 10 years, and during the preceding year she had a marked facial reaction to sun exposure. The medical history included recurrent urinary tract 
infections with pyelonephritis, recurrent staphylococcal infections including septic arthritis of the left knee, perirectal abscess, and deep venous thromboses. Physical examination was essentially within normal limits except for evidence of mitral valve prolapse. She was brought to our attention when we presented patient 1 at a local conference.

Complement measurements (Table I) showed strikingly decreased $\mathrm{CH}_{50}$ and hemolytic $\mathrm{C} 4$ values in the presence of normal $\mathrm{C} 4$ levels as measured immunologically. Subsequent immunologic measurements of $\mathrm{Clq}$ and $\mathrm{Cl}$ inhibitor were normal, and cryoglobulins could not be demonstrated in two tests lasting 7 days. Supporting a clinical diagnosis of probable systemic lupus erythematosus, the homogeneous ANA test titer had risen to 1:1280 by 1987 , and DNA binding by the Farr test was elevated at $28 \%$. Tests for anti-ENA antibodies have been positive, but anti-RNP, anti-Sm, anti-Ro, and anti-La tests have been negative. Other negative or normal results have included anti-cardiolipin antibodies, VDRL, WBC and differential, hepatitis B surface antigen, and nasal and rectal swabs for Staphylococcus aureus. The patient's parents and two siblings had been found to have normal $\mathrm{CH}_{50}$ levels and normal $\mathrm{C} 4, \mathrm{C} 3$, and $\mathrm{C} 1$ inhibitor values when measured immunologically.

More recently patient 2 has experienced recurrent arthralgias and episodes of pleuritic chest pain, and there have been two spontaneous abortions. Synovectomy of the left knee has been followed by the placement of a total knee prosthesis. Following sun exposure in 1990 she had a severe exacerbation of her disease including neurological symptoms. Exposure to cold has not produced difficulty other than Raynaud's phenomenon.

\section{MATERIALS AND METHODS}

Some blood samples were clotted for $1 \mathrm{hr}$ at $4^{\circ} \mathrm{C}$, centrifuged at that temperature, snap-frozen in aliquots in liquid $\mathrm{N}_{2}$, and stored at $-70^{\circ} \mathrm{C}$; other blood samples were placed in tubes prewarmed to $37^{\circ} \mathrm{C}$, transported to the laboratory in warmed sand at $37^{\circ} \mathrm{C}$, centrifuged at $37^{\circ} \mathrm{C}$, and immediately snapfrozen in aliquots; and additional blood samples were collected in tubes containing EDTA or heparin and the plasma snap-frozen in aliquots after centrifugation at $4^{\circ} \mathrm{C} . \mathrm{CH}_{50}$, hemolytic $\mathrm{C} 4$, and hemolytic $\mathrm{C} 1$ were assayed according to the methods of Kabat and Mayer (15), Cooper and Muller-Eberhard (16), and Borsos and Rapp (17), respectively. Similar procedures were used in another laboratory in the tests reported in Table I. Our hemolytic C4 values are based on reciprocal serum dilutions where $Z=$ 1 (16). C4a and C3a were determined by radioimmunoassay using an Upjohn Co. kit, and $\mathrm{C} 4 \mathrm{~d} / \mathrm{C} 4$ ratios were measured by rocket immunoelectrophoresis as described by Milgrom et al. (18). Experiments involving mixtures of serum containing CDAC factor(s), or precipitates therefrom, and normal serum employed the procedure of Atkinson $e t$ al. (10).

\section{$\mathrm{Cl} \overline{\mathrm{s}}-\mathrm{Cl} \mathrm{r}-(\mathrm{Cl} \mathrm{INH})_{2}$ Assays}

Anti-C1s serum was obtained from a goat immunized with C1s purified by the method of $\operatorname{Sim}(19)$, the antiserum being purified by affinity chromatography. C1 INH was purified by the method of Salvesen et al. (20). $\mathrm{C} 1 \overline{\mathrm{s}}-\mathrm{C} 1 \overline{\mathrm{r}}-(\mathrm{C} 1 \mathrm{INH})_{2}$ complexes were measured by the enzyme-linked immunosorbent assay (ELISA) procedure described by Harpel and Cooper (21) and subsequently modified according to the method of Nilsson and Back (22). Briefly, ELISA plates were coated overnight at $4^{\circ} \mathrm{C}$ with 1 $\mu \mathrm{g} / \mathrm{ml}$ of the affinity-purified goat anti-C1s or $\mathrm{F}\left(\mathrm{ab}^{\prime}\right)_{2}$ fragments therefrom. Following blocking with gelatin solution, test serum diluted in phosphatebuffered saline (PBS)-Tween with $20 \mathrm{mM}$ EDTA was introduced into the wells, and after overnight incubation at $4^{\circ} \mathrm{C} \mathrm{C1} \bar{s}-\mathrm{Cl} \overline{\mathrm{r}}-(\mathrm{Cl} \mathrm{INH})_{2}$ complexes were quantitated following sequential reactions with $2 \mu \mathrm{g} / \mathrm{ml}$ mouse monoclonal anti-C1 INH, 1:5500 human adsorbed peroxidase-conjugated goat anti-mouse IgG serum (Caltag Labs, San Francisco, $\mathrm{CA}$ ), and enzyme substrate. Control wells were coated with normal goat IgG. In agreement with Nilsson et al. (22), it was found that in order to compare results at different serum dilutions, it is necessary to precipitate out inhibitory C1qrs complexes by the addition of polyethylene glycol (PEG) 6000 to a final concentration of $6 \%(\mathrm{w} / \mathrm{v})$ before diluting the serum with EDTA-containing buffer. Resulting OD readings were compared with a linear standard curve generated by serial dilutions of PEG-precipitated normal human serum which had been activated by $1 \mathrm{mg} / \mathrm{ml}$ of heat-aggregated $\gamma$-globulin and which had arbitrarily been assigned a value of 1000 units (23). The intraassay coefficient of variation averaged $\pm 5.9 \%$, and previous freezing and thawing of sera three times did not influence the results. 


\section{Protein G Adsorption Tests}

Protein G-Sepharose was purchased from Pharmacia (Piscataway, NJ). Patient or control EDTA plasma was agitated for $30 \mathrm{~min}$ at room temperature (RT) with a double volume of washed protein G-Sepharose beads or anti-human albuminconjugated Sepharose. $\mathrm{CaCl}_{2}$ was added to the supernatants to a concentration of $14 \mathrm{mM}$. After removing the clots, the tubes were incubated for 2.5 hr at $12^{\circ} \mathrm{C}$ and divided into aliquots for $\mathrm{C} 4 \mathrm{~d} / \mathrm{C} 4$ and $\mathrm{C} 1 \overline{\mathrm{r}}-\mathrm{Cl} \overline{\mathrm{s}}-(\mathrm{Cl} \mathrm{INH})_{2}$ tests. Controls included unadsorbed plasma.

\section{Inhibition by Heat and Restoration with Cl}

A redissolved euglobulin precipitate of normal serum was the source of the $\mathrm{Cl}$ used in this test as well as in the hemolytic assays. Aliquots of patient 1 serum obtained at $37^{\circ} \mathrm{C}$ were refrozen at once or were incubated for $2 \mathrm{hr}$ at $4^{\circ} \mathrm{C}$ before refreezing. Other aliquots were heated at $56^{\circ} \mathrm{C}$ for $15 \mathrm{~min}$ before being either immediately refrozen, incubated for $2 \mathrm{hr}$ at $4^{\circ} \mathrm{C}$, incubated for $2 \mathrm{hr}$ at $4^{\circ} \mathrm{C}$ following the addition of $\mathrm{Cl}$, or incubated for $2 \mathrm{hr}$ at $4^{\circ} \mathrm{C}$ after the addition of $\mathrm{C} 1$ which had previously been heated at $56^{\circ} \mathrm{C}$ for $30 \mathrm{~min}$. The $\mathrm{C} 1$ was dissolved in PBS containing $0.15 \mathrm{mM} \mathrm{CaCl}{ }_{2}$, and either this or buffer alone was added to $3 \mathrm{vol}$ of serum in all aliquots. The final concentration of reconstituted $\mathrm{C} 1$ approximated that of normal serum. The various aliquots were subdivided for subsequent testing for $\mathrm{C} 4 \mathrm{~d} / \mathrm{C} 4$ ratio, $\mathrm{C} 1 \overline{\mathrm{s}}-\mathrm{C} 1 \overline{\mathrm{r}}-(\mathrm{Cl} \mathrm{INH})_{2}$ content and hemolytic $\mathrm{C} 4$.

\section{RESULTS}

\section{Recognition of CDAC}

Attention initially was focused on the striking discrepancy between patient 1's total absence of C4 hemolytic activity and the presence of normal $\mathrm{C} 4$ levels as measured immunologically. Considering the possibility of an unusual C4 abnormality (e.g., abnormally glycosylated or incompletely processed pro-C4), sera from eight family members were tested for $\mathrm{CH}_{50}$, hemolytic $\mathrm{C} 4$, and $\mathrm{C} 4$ antigen, but all were normal. Activation of the classical pathway would be the most obvious possibility, but lack of clinical evidence for immune complex disease, normal ESR, absence of precipitable cryoproteins, normal levels of $\mathrm{Clq}, \mathrm{C} 4$, and $\mathrm{C} 3$ antigen, nearly
Table II. Anaphylatoxin Measurements by Radioimmunoassay

\begin{tabular}{|c|c|c|}
\hline & $\begin{array}{c}\mathrm{C} 4 \mathrm{a} \\
(\mathrm{ng} / \mathrm{ml})\end{array}$ & $\underset{(\mathrm{ng} / \mathrm{ml})}{\mathrm{C} 3 \mathrm{a}}$ \\
\hline \multicolumn{3}{|l|}{ A. Specimens collected at $4^{\circ} \mathrm{C}$} \\
\hline Patient 1 serum & $16,980(96)^{a}$ & $51,250(31)$ \\
\hline Normal serum & $1,013 \quad(8.7)$ & $5,110(4.3)$ \\
\hline \multicolumn{3}{|l|}{ Patient 1 serum + zymosan } \\
\hline \multicolumn{3}{|l|}{ Normal serum + zymosan } \\
\hline+ aggregated $\lg G$ & 11,620 & 119,000 \\
\hline Patient 1 EDTA plasma & 181 & 202 \\
\hline Normal EDTA plasma & 175 & 97 \\
\hline \multicolumn{3}{|c|}{ B. Patient 1 specimens collected at $37^{\circ} \mathrm{C}$} \\
\hline \multicolumn{3}{|l|}{ Hours incubated at $37^{\circ} \mathrm{C}$} \\
\hline 0 & $289 \quad(1.3)$ & $4,600 \quad(7.7)$ \\
\hline 1.5 & $465 \quad(2.1)$ & $5,016 \quad(8.4)$ \\
\hline 3 & $959 \quad(4.3)$ & $3,760 \quad(6.3)$ \\
\hline \multicolumn{3}{|l|}{ Hours incubated at $4^{\circ} \mathrm{C}$} \\
\hline 0 & $587 \quad(2.6)$ & $3,280 \quad(5.5)$ \\
\hline 1.5 & $4,413 \quad(19.6)$ & $7,145(11.9)$ \\
\hline 3 & $23,092(100)$ & $8,983(15.0)$ \\
\hline
\end{tabular}

${ }^{a}$ Percentage of activatable $\mathrm{C} 4$ or $\mathrm{C} 3$.

normal levels of hemolytic $\mathrm{C} 2$, and exclusion of $\mathrm{C} 1$ inhibitor deficiency at first detracted from this consideration. However, measurement of $\mathrm{C} 4 \mathrm{a}$ and $\mathrm{C} 3 \mathrm{a}$ serum levels provided striking evidence of $\mathrm{C} 4$ and C3 cleavage, but unlike most cases of in vivo complement activation, the total activatable $\mathrm{C} 4$ and C3 levels also were somewhat above normal (Table IIA). Although there was a substantial amount of C3a detected, the percentage C3 cleavage was lower than $\mathrm{C} 4$ cleavage as is common in fluid-phase classical complement pathway activation. Of even greater interest was the concomitant normal $\mathrm{C} 4 \mathrm{a}$ level measured in EDTA plasma, and subsequently it was shown that $\mathrm{CH}_{50}$ and hemolytic $\mathrm{C} 2$ levels also were normal in patient 1's EDTA or citrate plasma. These data suggested the diagnosis of CDAC. It resulted from the procedure at that time of sending blood for serum hemolytic complement levels to the pathology laboratory on ice, whereas in EDTA plasma $\mathrm{C} 1$ activation is inhibited by the chelation of $\mathrm{Ca}^{2+}$ by EDTA.

\section{Testing for CDAC}

In general, documenting CDAC involves demonstrating functional classical pathway activation in chilled serum but not in (a) cold EDTA plasma or (b) serum obtained from blood maintained at $37^{\circ} \mathrm{C}$. The latter requires meticulous specimen collection (see Materials and Methods) but permits one to study mechanisms of CDAC by subsequent con- 


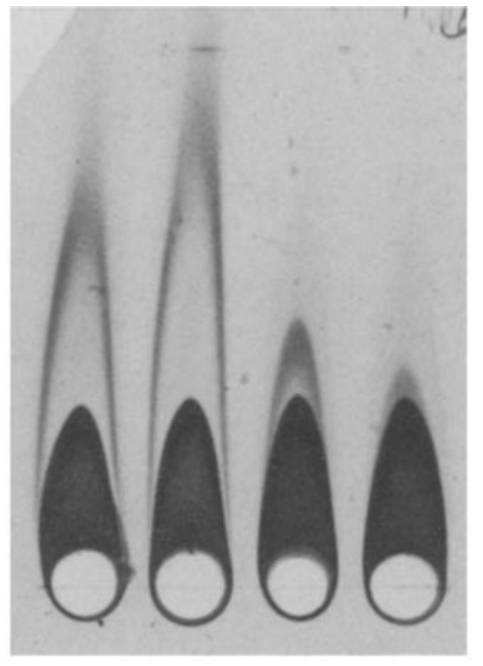

$\begin{array}{lcccc}\text { Incubation } & 4^{\circ} \mathrm{C} & 13^{\circ} \mathrm{C} & 24^{\circ} \mathrm{C} & \text { none } \\ \mathrm{C} 4 \mathrm{~d} / \mathrm{C} 4 \text { ratio } & 2.37 & 3.06 & 1.19 & 1.13 \\ \mathrm{C} 1 \overline{\mathrm{s}}-\mathrm{Cl} \overline{\mathrm{r}}-\mathrm{C} 1 \mathrm{INH})_{2} & 337^{\mathrm{a}} & 1157 & 177 & 85 \\ \text { Hemolytic C4 } & 20^{\mathrm{b}} & <5 & 90 & 100 \\ & & & & \\ & \text { a ELISA units } \\ & \text { b \% of normal }\end{array}$

Fig. 1. Rocket immunoelectrophoresis for $\mathrm{C} 4 \mathrm{~d} / \mathrm{C} 4$ ratio, $\mathrm{Cls}-$ $\mathrm{C} 1 \overline{\mathrm{r}}-(\mathrm{Cl} \mathrm{INH})_{2}$ ELISA measurements and hemolytic $\mathrm{C} 4$ titers on freshly thawed patient $137^{\circ} \mathrm{C}$ serum $(12-8-86)$ before and after 4 hr at 4,13 , and $24^{\circ} \mathrm{C}$.

trolled activation in the cold. As in some previously reported cases, our attention was directed to a complement abnormality by finding an unexpectedly low $\mathrm{CH}_{50}$ level, and subsequent $\mathrm{CH}_{50}$ measurements in warm and chilled serum and in EDTA plasma yielded a pattern typical for CDAC. The $\mathrm{CH}_{50}$ levels in chilled serum from patient 1 all were $<22$ u $(N=6), 37^{\circ} \mathrm{C}$ serum levels were $110 \pm 13 \mathrm{u}$ $(N=7)$, and EDTA plasma levels were 78 and 105 u. However, other methods of measuring complement activation provide more incisive evidence of classical pathway activation, greater sensitivity, or more convenience.

Figure 1 shows measurements of CDAC activity in freshly thawed serum from patient 1 obtained on 12-8-86 before and after incubation for $4 \mathrm{hr}$ at 24,13 , or $4^{\circ} \mathrm{C}$. Measurements were performed by rocket immunoelectrophoresis (IEP) for C4d generation, hemolytic $\mathrm{C} 4$ titration, and $\mathrm{C} 1 \overline{\mathrm{s}}-\mathrm{C} 1 \overline{\mathrm{r}}-(\mathrm{Cl} \mathrm{INH})_{2}$ complex testing. Quantitation of IEP results was

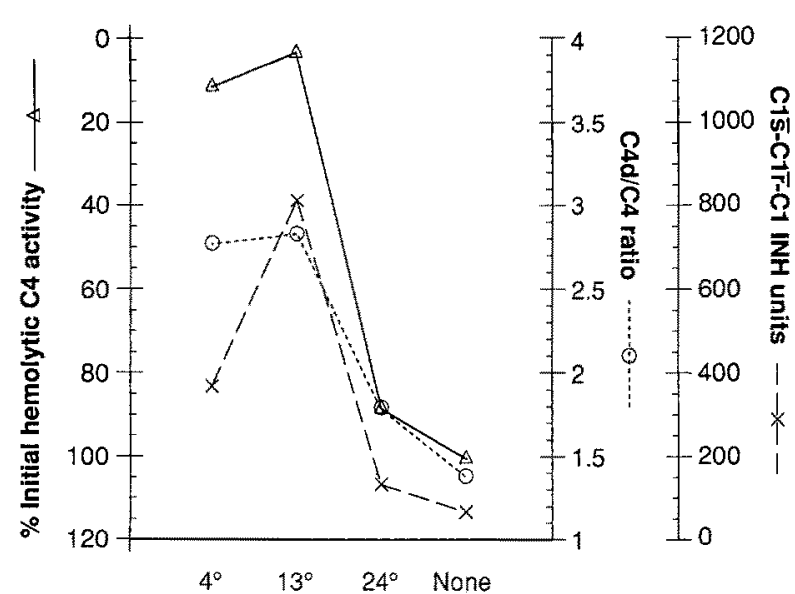

Fig. 2. Measurements of percentage initial hemolytic activity $(\triangle), \mathrm{C} 4 \mathrm{~d} / \mathrm{C} 4$ ratio $(\mathrm{O})$, and $\mathrm{Cl}-\mathrm{s}-\mathrm{Cl} \overline{\mathrm{r}}-(\mathrm{Cl} \mathrm{INH})_{2}$ ELISA units $(\mathrm{X})$ before and after incubating patient 1 serum obtained at $37^{\circ} \mathrm{C}$ (4-12-88) for $4 \mathrm{hr}$ at 24,13 , or $4^{\circ} \mathrm{C}$.

achieved by measuring planimetrically the area encompassed by the upper $\mathrm{C} 4 \mathrm{~d}$ rocket and the area of the more sharply delineated $\mathrm{C} 4$ rocket; normally the $\mathrm{C} 4 \mathrm{~d} / \mathrm{C} 4$ ratio is $<1.2(18)$. For comparison with the other data, the hemolytic $\mathrm{C} 4$ titers are expressed as a percentage of the unincubated specimen value. Figure 2 shows similar evidence for CDAC activity as assessed by these three tests in serum obtained on 4-12-88; additional tests yielded the same results on serum obtained on 4-4-90. The finding of greater CDAC activity at 13 than at $4^{\circ} \mathrm{C}$ was confirmed in five additional experiments including three using patient 2 serum. Earlier observations employing $\mathrm{CH}_{50}$ measurements of serum from patient 1 showed no evidence of CDAC at 32 or $29^{\circ} \mathrm{C}$, but beginning complement activation was observed at $26^{\circ} \mathrm{C}$. Serum obtained from patient 1 at $37^{\circ} \mathrm{C}$ required chilling for $3 \mathrm{hr}$ at $4^{\circ} \mathrm{C}$ to achieve maximal complement activation. As shown in Table IIB, measurements of $\mathrm{C} 4 \mathrm{a}$ and $\mathrm{C} 3 \mathrm{a}$ generation in chilled patient 1 serum or recalcified EDTA plasma yielded results similar to those of the previously mentioned tests. Normal serum does not show this response to cold. Patient 2 serum also showed greater $\mathrm{C} 4 \mathrm{a}$ generation at 4 than at $37^{\circ} \mathrm{C}$, while $\mathrm{C} 4 \mathrm{a}$ and $\mathrm{C} 3 \mathrm{a}$ levels in EDTA plasma were significantly lower (data not shown). Another test for CDAC factor(s) is to demonstrate its capacity to activate complement in normal serum after mixing in the cold (10). The higher level of $\mathrm{C} 1 \overline{\mathrm{s}}-\mathrm{C} 1 \overline{\mathrm{r}}-(\mathrm{C} 1 \mathrm{INH})_{2}$ complexes and lower hemolytic $\mathrm{C} 4$ values seen in column 3 in Table III than in column 5 indicate that activation of normal serum complement has occurred. The fact 
Table III. Activation of Normal Serum Complement by Incubation with CDAC Serum at $4^{\circ} \mathrm{C}$ for $24 \mathrm{hr}$

\begin{tabular}{|c|c|c|c|c|c|}
\hline & $\mathrm{KMs}^{a}+\mathrm{VB}^{++b}$ & Pt. $1^{c} \stackrel{(2)}{+} \mathrm{VB}^{++}$ & $\begin{array}{c}\text { (3) } \\
\text { Pt. 1s + KMs }\end{array}$ & $\begin{array}{c}(4) \\
\mathrm{BZs}^{a}+\mathrm{KMs}\end{array}$ & $\begin{array}{c}(5) \\
(1+2)\end{array}$ \\
\hline $\mathrm{C} 4 \mathrm{~d} / \mathrm{C} 4$ ratio & 1.0 & 2.33 & $>2.62$ & 1.0 & \\
\hline $\begin{array}{l}\mathrm{C} 1 \overline{\mathrm{s}}-\mathrm{C} 1 \mathrm{r}-(\mathrm{C} 1 \mathrm{INH})_{2} \\
\text { (ELISA units) }\end{array}$ & 33 & 470 & 774 & 25 & 503 \\
\hline $\begin{array}{l}\text { Hemolytic C4 } \\
\text { (\% normal) }\end{array}$ & 49 & 0 & $<2$ & 79 & 49 \\
\hline
\end{tabular}

Normal serum.

${ }^{b}$ Veronal buffer with $\mathrm{Ca}$ and $\mathrm{Mg}$.

${ }^{\circ} \mathrm{CDAC}$ patient serum.

that the $\mathrm{C} 4 \mathrm{~d} / \mathrm{C} 4$ ratio in column 3 exceeds the average of columns 1 and 2 also supports this conclusion. Similar results were obtained in six other experiments.

\section{Assessing the Mechanisms of CDAC}

Supporting previous data suggesting that the CDAC factor(s) is IgG (10), Table IV shows results representative of three experiments in which patient 1 plasma and control EDTA plasma were batched-adsorbed by protein G-Sepharose. In other

Table IV. Adsorption of CDAC Factor(s) from EDTA Plasma by Protein G-Sepharose

\begin{tabular}{|c|c|c|c|c|}
\hline & \multicolumn{2}{|c|}{ Unadsorbed } & \multicolumn{2}{|c|}{ Adsorbed } \\
\hline & $25^{\circ} \mathrm{C}$ & $12^{\circ} \mathrm{C}$ & $\begin{array}{l}\text { Protein } \\
\mathrm{G}, 12^{\circ} \mathrm{C}\end{array}$ & $\begin{array}{l}\text { Anti- } \\
\text { albumin, } \\
12^{\circ} \mathrm{C}\end{array}$ \\
\hline \multicolumn{5}{|l|}{ Patient $1^{a}$} \\
\hline $\mathrm{C} 4 \mathrm{~d} / \mathrm{C} 4$ ratio & 1.05 & 2.17 & 1.10 & 1.41 \\
\hline $\mathrm{C} 1 \overline{\mathrm{s}}-\mathrm{C} 1 \overline{\mathrm{r}}-(\mathrm{Cl} \mathrm{INH})_{2}$ & $0.436^{b}$ & 1.440 & 0.322 & 0.900 \\
\hline \multicolumn{5}{|l|}{ Normal $^{a}$} \\
\hline $\mathrm{C} 4 \mathrm{~d} / \mathrm{C} 4$ ratio & 1.13 & 1.14 & 1.15 & \\
\hline $\mathrm{C} 1 \overline{\mathrm{s}}-\mathrm{C} 1 \overline{\mathrm{r}}-(\mathrm{Cl} \mathrm{INH})_{2}$ & 0.589 & 0.454 & 0.382 & \\
\hline
\end{tabular}

${ }^{a}$ EDTA plasma recalcified after adsorption.

${ }^{b}$ OD value. experiments it was shown that more than $99 \%$ of the IgG was removed by this procedure. Results of both the $\mathrm{C} 4 / \mathrm{C} 4 \mathrm{~d}$ and the $\mathrm{C} 1 \bar{s}-\mathrm{C} 1 \overline{\mathbf{r}}-(\mathrm{C} 1 \mathrm{INH})_{2}$ tests indicate an accompanying marked loss in CDAC activity which was much greater than that following adsorption with anti-human serum albumin Sepharose. It was necessary to do these adsorptions in EDTA plasma (followed by recalcification) rather than in serum, because the latter procedure resulted in significant complement activation.

Table $\mathrm{V}$ shows the results of an experiment in which patient 1 and normal sera were precipitated by $2.5 \%$ PEG in PBS with $20 \mathrm{~m} M$ EDTA for $2 \mathrm{hr}$ at $4^{\circ} \mathrm{C}$. After washing with $2.5 \%$ PEG in PBS, the precipitates were (largely) dissolved in $37^{\circ} \mathrm{C}$ Veronal buffer, mixed with normal serum, incubated for $22 \mathrm{hr}$ at $4^{\circ} \mathrm{C}$, and aliquoted for $\mathrm{C} 4 \mathrm{~d} / \mathrm{C} 4$, $\mathrm{C} 1 \overline{\mathrm{s}}-\mathrm{C} 1 \overline{\mathrm{r}}-(\mathrm{Cl} \mathrm{INH})_{2}$, and hemolytic $\mathrm{C} 4$ assays. As shown in Table $\mathrm{V}$, results from all three tests showed substantial complement activation at $4^{\circ} \mathrm{C}$ after mixing the redissolved $\mathrm{PEG}$ precipitate from patient 1 with normal serum, whereas the PEG precipitate from normal serum (B.Z.) did not have this effect. This indicates that the CDAC factor(s) is included among the substances precipitated by 2.5\% PEG.

Table V. Activation of Complement in Normal Serum by 2.5\% Polyethylene Glycol (PEG) Precipitate of Patient 1 Serum

\begin{tabular}{|c|c|c|c|c|c|c|c|}
\hline & $\begin{array}{c}\text { Pt. I } \\
\text { ppt. }\end{array}$ & $\begin{array}{l}\text { Pt. } 1 \text { ppt. } \\
\text { VB }^{++d}\end{array}$ & $\begin{array}{l}\mathrm{KMs}^{e}+ \\
\text { Pt. } 1 \text { ppt }^{a}\end{array}$ & $\underset{\mathrm{KB}^{++}}{\mathrm{KMs}^{+}}$ & $\underset{\text { N1s ppt. }}{\text { KMs }+}$ & $\underset{\mathrm{VB}^{++}}{\mathrm{N} 1 \mathrm{~s} p \mathrm{f}^{f}}{ }^{+}$ & $\mathrm{KM}^{b, c}$ \\
\hline $\mathrm{C} 4 \mathrm{~d} / \mathrm{C} 4$ ratio & $\overline{\mathrm{ND}^{g}}$ & $\mathrm{ND}$ & 2.12 & 1.0 & 1.0 & & 1.0 \\
\hline $\begin{array}{l}\text { (ELISA units) } \\
\text { Hemolytic C4 (\% normal) }\end{array}$ & 0 & $\begin{array}{l}0 \\
0\end{array}$ & $\begin{array}{r}428 \\
<1\end{array}$ & $\begin{array}{l}33 \\
49\end{array}$ & $\begin{array}{l}38 \\
46\end{array}$ & $\begin{array}{l}0 \\
0\end{array}$ & $\begin{array}{l}31 \\
86\end{array}$ \\
\hline
\end{tabular}

${ }^{a}$ Redissolved patient 1 PEG precipitate.

${ }^{b}$ Not incubated at $4^{\circ} \mathrm{C}$. All others incubated for $24 \mathrm{hr}$ at $4^{\circ} \mathrm{C}$.

'Undiluted.

${ }^{d}$ Equal volume of Veronal buffer with $\mathrm{Ca}^{2+}$ and $\mathrm{Mg}^{2+}$.

Normal serum.

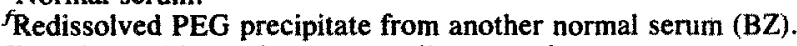

${ }^{8}$ Not detectable; rockets too small to quantitate. 
Table VI. Inhibition of CDAC by Heat and Restoration by $\mathrm{C} 1$

\begin{tabular}{|c|c|c|c|c|c|c|}
\hline & \multicolumn{2}{|c|}{ Unheated serum } & \multicolumn{4}{|c|}{ Heated $15 \mathrm{~min}$ at $56^{\circ} \mathrm{C}$} \\
\hline & $\begin{array}{c}\text { Not } \\
\text { incubated }\end{array}$ & $\begin{array}{c}2 \mathrm{hr} \text { at } \\
4^{\circ} \mathrm{C}\end{array}$ & $\begin{array}{c}\text { Not } \\
\text { incubated }\end{array}$ & $\begin{array}{c}2 \mathrm{hr} \text { at } \\
4^{\circ} \mathrm{C}\end{array}$ & $\begin{array}{c}2 \mathrm{hr} \text { at } 4^{\circ} \mathrm{C} \\
+\mathrm{C} 1\end{array}$ & $\begin{array}{c}2 \mathrm{hr} \text { at } 4^{\circ} \mathrm{C} \\
+ \text { heated } \\
\text { Cl }\end{array}$ \\
\hline \multirow{3}{*}{$\begin{array}{l}\mathrm{C} 4 \mathrm{~d} / \mathrm{C} 4 \text { ratio } \\
\mathrm{C} 1 \mathrm{~s}-\mathrm{C} 1 \mathrm{f}-(\mathrm{Cl} \mathrm{INH})_{2} \\
\text { Hemolytic C4 } \\
(\% \text { normal })\end{array}$} & 1.04 & 1.83 & 1.77 & 1.81 & 2.67 & 1.88 \\
\hline & $46^{a}$ & 121 & $\sim 5$ & & 105 & 9 \\
\hline & 66 & 21 & 12 & 11 & $\sim 0$ & 12 \\
\hline
\end{tabular}

In view of the significantly low levels of hemolytic C4 in our patients' sera and the variable and sometimes almost-normal levels of hemolytic C2 and $\mathrm{C} 1$, consideration was given to the possible presence of a cold-reactive autoantibody to $\mathrm{C} 4$ causing secondary activation of the classical pathway. This was explored by a series of more than 30 ELISA tests using wells coated with human $\mathrm{C} 4$ or with goat anti-human $\mathrm{C} 4$, the latter being employed to test for possible $\mathrm{IgG}: \mathrm{C} 4$ complexes. Patient 1 serum usually gave higher OD readings than control sera, but it also gave higher OD measurements in wells coated with various heterologous materials: specific autoantibodies to $\mathrm{C} 4$ could not be demonstrated.

Considering the possibility that $\mathrm{CDAC}$ might have a direct effect on $\mathrm{C} 4$ other than through an autoantibody mechanism, the effect of heating patient 1 serum at $56^{\circ} \mathrm{C}$ for $15 \mathrm{~min}$ was examined. As expected, heating per se caused some $\mathrm{C} 4$ cleavage and loss of $\mathrm{C} 4$ hemolytic activity in addition to loss of CDAC (Table VI), but CDAC activity was restored by the addition of $\mathrm{Cl}$ but not by heat inactivated $\mathrm{C} 1$. This requirement for $\mathrm{C} 1$, which was reproduced in another experiment, is characteristic for classical complement pathway activation and opposes a direct effect of CDAC factor(s) on $\mathrm{C} 4$ or $\mathrm{C} 4$ binding protein.

\section{Effect of a CDAC Factor(s) on Other Tests}

Since CDAC factor(s) may be a form of aggregated IgG, patient 1 serum obtained at $37^{\circ} \mathrm{C}$ was incubated for 3 or $5 \mathrm{hr}$ at either 4 or $37^{\circ} \mathrm{C}$, and the effect on Raji cell tests was noted. The positive results, averaging $197 \mu \mathrm{g} \mathrm{AHG} \mathrm{Eq/ml} \mathrm{(normal,} \mathrm{<50}$ AHG Eq/ml), were essentially the same after incubation at either temperature. Likewise chilling the serum for 3 or $5 \mathrm{hr}$ at $4^{\circ} \mathrm{C}$ did not change the borderline results of patient 1 's $\mathrm{Clq}$ binding assay.
Since FACS analyses involve incubating cells in the cold and about $26 \%$ of patient 1's lymphoid cells did not demonstrate the usual markers, the effect of incubating normal peripheral WBC with her heparinized plasma for $1.5 \mathrm{hr}$ at $4^{\circ} \mathrm{C}$ was determined to see if her plasma might interfere with this test. However, there was no change in the percentage of cells expressing CD3, CD4, CD8, or CD19 markers as compared with unincubated cells or cells incubated with normal plasma.

\section{DISCUSSION}

Since CDAC is an in vitro phenomenon, afflicted individuals do not experience difficulty upon exposure to cold as in some other immune cryopathies such as cryoglobulinemia, cryofibrinogenemia, cold urticaria, or cold hemolysin syndrome. CDAC also clearly differs in mechanism from cases of coldpromoted activation (CPA) of blood coagulation factor VII (24) mediated through contact system activation and from cold-dependent consumption of C3 (25) mediated through the alternative complement pathway. Hishitani et al. (26) have reported that the occurrence of a CDAC-type phenomenon in patients with liver disease often is associated with precipitable mixed cryoglobulins. However, centrifugation of serum from our patients 1 and 2 after 7 days at $4^{\circ} \mathrm{C}$ repeatedly yielded no visible precipitate, and others have failed to find cryoprecipitates in cases not associated with liver disease. Another difference between CDAC and some cases of cryoglobulinemia is a decreased level of $\mathrm{C} 1 \mathrm{q}$ and $\mathrm{C} 4$ antigen in the latter (27), whereas the lack of immune complex sequestration in vitro results in normal values in CDAC even though split products can be detected and hemolytic activity is compromised. Thus, in accord with most other investigators, we have used the term CDAC in a more restricted sense which excludes cryoglobulinemia 
and the cold hemolysin syndrome. Perhaps a better term would be "idiopathic cold-dependent activation of complement."

CDAC was initially recognized by discrepant $\mathrm{CH}_{50}$ and hemolytic $\mathrm{C} 4$ values between serum obtained at $4^{\circ} \mathrm{C}$ and those measured in EDTA plasma. Here it has been shown that measurements of $\mathrm{C} 4 \mathrm{~d} / \mathrm{C} 4$ ratios, $\mathrm{C} 4 \mathrm{a}, \mathrm{C} 3 \mathrm{a}$, and $\mathrm{Cl} \bar{s}-\mathrm{Cl} \overline{\mathrm{r}}-(\mathrm{Cl} \mathrm{INH})_{2}$ complexes also can be used to document CDAC and that results obtained by these various methods parallel each other. No doubt other tests of classical complement pathway activation also could be utilized. The choice of which procedure to use therefore becomes largely a matter of convenience, rocket immunoelectrophoresis for $\mathrm{C} 4 \mathrm{~d} / \mathrm{C} 4$ ratios and $\mathrm{CH}_{50}$ measurements being relatively simple. Hemolytic C4 measurements clearly provide the greatest sensitivity, but for some research purposes this can be disadvantageous; e.g., some lots of serum already had low hemolytic $\mathrm{C} 4$ values when blood supposedly obtained and processed at $37^{\circ} \mathrm{C}$ was not meticulously handled, and in some instances there was so much loss of hemolytic $\mathrm{C} 4$ activity at $4^{\circ} \mathrm{C}$ that it was difficult to appreciate the difference from results at $13^{\circ} \mathrm{C}$ that were more easily recognized by other methods (Fig. 2). This may be one reason why previous investigators have not noted that the optimal temperature for CDAC may be between $4^{\circ} \mathrm{C}$ and room temperature. Possibly more of the factor(s) responsible for CDAC aggregates at the lower temperature (i.e., $4^{\circ} \mathrm{C}$ ), but consequent complement activation is enhanced at a higher temperature (e.g., $\left.13^{\circ} \mathrm{C}\right)$. The data indicating complement activation when normal serum is mixed with CDAC serum at $4^{\circ} \mathrm{C}$ (Table III) confirm similar previous results of Kitamura et al. (8) and Atkinson et al. (10). The opportunity to test serum from patient 1 over a period of more than 5 years establishes that CDAC may be more than a transient phenomenon.

Our observation that CDAC activity is reduced by adsorption with streptococcal protein G-Sepharose (Table IV) supports the conclusion of Atkinson et al. (10) that it is IgG based on partial purification by ammonium sulfate precipitation at $4^{\circ} \mathrm{C}$ followed by DEAE column chromatography at room temperature. The additional observation that CDAC activity is precipitated by $2.5 \%$ PEG strongly implies that polymeric IgG is involved, since monomeric IgG would not be expected to precipitate significantly at this PEG concentration (28). The presence of CDAC activity in $2.5 \%$ PEG precipitates, as shown by mixing with normal serum (Table V), augments the finding of Takemura et al. (12) that such precipitates are anticomplementary. In interpreting these results it should be noted that, in addition to precipitating proteins, PEG has been reported to enhance the aggregation of IgG by IgM rheumatoid factor (29). Hishitani et al. (26) reported that the precipitable cryoglobulin in their (mainly) liver disease patients which produced features of CDAC was a mixed cryoglobulin consisting of IgM and polyclonal IgG. Patient 1 serum, however, had only minimal rheumatoid factor activity, and the partial purification procedure employed by Atkinson et al. (10) should largely exclude IgM. Many monoclonal IgG cryoimmunoglobulins are IgG3, but patient 1 did not have an elevated IgG3 serum level. Accordingly, one may speculate that the factor(s) responsible for CDAC in our patients, and in others without cryoprecipitates, contains polymeric IgG in a form too small or otherwise incapable of precipitating spontaneously in the cold. An alternative would be antigen-containing immune complexes of similar size and physical properties. In patient 1 , however, the extensive testing noted above for antibodies to many exogenous and autologous antigens has yielded negative results. $\mathrm{Re}$ gardless of the exact nature of the CDAC factor(s) in these patients, they appear to act through activation of the classical complement pathway. Unexpectedly high hemolytic $\mathrm{C} 2$ levels in relation to hemolytic $\mathrm{C} 4$ have also been noted in patients with hereditary angioedema (30) and might be due to reduced cleavage of $\mathrm{C} 2$ in the absence of $\mathrm{C} 4$. The cascade principle of complement activation of course would predict less evidence for $\mathrm{C} 1$ than $\mathrm{C} 4$ activation. Autoantibodies to $\mathrm{C} 4$ with secondary activation of the classical pathway could not be demonstrated.

\section{ACKNOWLEDGMENTS}

The assistance of R. J. Ziccardi, G. D. Till, E. S. Tucker, J. L. Wagner, P. M. Pan, K. Cox, B. Bradt, and C. Kane with various aspects of this work is gratefully acknowledged. The sustained cooperation of both patients also was greatly appreciated.

This work was supported in part by NIH Grants AI10386, AI32834, HL25658, and RR-00833 to the Scripps Clinic and Research Foundation and 5 MD1-RR00042-22 to the university of Michigan Clinical Research Center. 


\section{REFERENCES}

1. Gewurz H, Baron J, Ratnoff DD, Yachnin S: Coagulationassociated consumption of complement: A case with dissociation between serum and plasma complement activities. $J$ Clin Invest 49:39A, 1970

2. Glovsky MM, Alenty A: Coagulation related deficiencies of early components of $\mathrm{C}(\mathrm{Cl}, \mathrm{C} 4, \mathrm{C} 2)$ in human serum. $\mathrm{J}$ Immunol 111:305, 1973

3. Gewurz $\mathrm{H}$ : Nonimmune activation of $\mathrm{C}$ : Two new phenomena. J Immunol 111:305, 1973

4. Glovsky M, Inai S, Nagaki K, Tejima $H$ : Permutations in early components of complement $(\mathrm{C} 1, \mathrm{C} 4, \mathrm{C} 2)$ in man. Fed Proc 33:647, 1974

5. Inai S, Kitamura H, Fujita T, Kohima J, Nasaki K: Differences between plasma and serum complement in patients with chronic liver disease. Clin Exp Immunol 25:403-409, 1976

6. Kitamura $H$, Nagaki $K$, Inai $S$ : Cold activation of the classical complement pathway found in patients with chronic liver disease. J Immunol 116:1738-1739, 1976

7. Kondo M, Hosokawa $\mathrm{K}$, Masuda $\mathrm{M}$ : Cold activation of complement. I. Presence of coagulation-related activator. J Immunol 117:486-490, 1976

8. Kitamura $H$, Nagaki $K$, Inoshita $K$, Iida $K$, Inai $S$ : The cold activation of the classical complement pathway: The cause of the differences between plasma and serum complement in liver cirrhosis. Clin Exp Immunol 27:34-37, 1977

9. Akagaki Y, Fujiwara Y, Nakanishi I, et al.: The difference between serum and plasma complement activity in primary renal disease. Clin Nephrol 14:75-80, 1980

10. Atkinson JP, Gorman JC, Curd J, et al.: Cold dependent activation of complement in systemic lupus erythematosus. A unique cause for a discrepancy between clinical and laboratory parameters. Arth Rheum 24:592-601, 1981

11. Matsuo T, Matsuoka Y, Umegaki K: Studies on inhibition of cold activation of complement. Jap J Clin Pathol 30:543-546, 1982

12. Takemura S, Hotta T, Matsumura N, Yoshikawa T, Kondo M: Cold activation of complement. Arth Rheum 25:11381140,1982

13. Yukiyama $\mathrm{Y}$, Yoshida $\mathrm{K}$, Hirose S: Complement activation at low temperature. Arerugi 33:275-281, 1984

14. Newell S, Gorman JC, Bell E, Atkinson JP: Hemolytic and antigenic measurements of complement. A comparison of serum and plasma samples in normal individuals and patients. J Lab Clin Med 100:437-444, 1982

15. Kabat EA, Mayer MM: Experimental Immunochemistry, Springfield, IL, Thomas, 1967, p 133

16. Cooper NR, Muller-Eberhard HJ: A comparison of methods for the molecular quantitation of the fourth component of complement. Immunochemistry 5:155-169, 1968
17. Borsos T, Rapp HJ: Chromatographic separation of the first component of complement and its assay on a molecular basis. J Immunol 91:851-858, 1963

18. Milgrom H, Curd JG, Kaplan RA, Muller-Eberhard HJ, Vaughan JH: Activation of the fourth component of complement (C4): Assessment by rocket immunoelectrophoresis and correlation with the metabolism of $\mathrm{C} 4$. J Immunol 124:2780-2785, 1980

19. Sim RB: The human complement system serine proteases $\mathrm{C} 1 \mathrm{r}$ and $\mathrm{C} 1 \mathrm{~s}$ and their proenzymes. Methods Enzymol $80: 26-42,1981$

20. Salvesen GS, Catauese JM, Kress LF, Travis J: Primary structure of the reactive site of human $\mathrm{C} 1$-inhibitor. J Biol Chem 260:2432-2436, 1985

21. Harpel PC, Cooper NR: Circulating $\mathrm{Cl}$ inactivator-C1s-C1r complexes: Quantification by an enzyme-linked differential antibody immunosorbent assay. Clin Res 30:563A, 1982

22. Nilsson T, Back O: Determination of $\mathrm{C} 1 \mathrm{~s}-\mathrm{C} 1$ inhibitor complexes in plasma by means of an enzyme linked immunosorbent assay. Clin Exp Immunol 60:178-182, 1985

23. Waldo FB, West CD: Quantitation of $(\mathrm{Cl} \mathrm{INH})_{2} \mathrm{Clr}$-Cls complexes in glomerulonephritis as an indicator of $\mathrm{Cl}$ activation. Clin Immunol Immunopathol 42:239-249, 1987

24. Gzendlik C, Lammle B, Duckert F; Cold promoted activation and factor VII, prekallikrein and $\mathrm{Cl}$ inhibitor. Thrombos Haemostas 53:242-244, 1985

25. Day NK, Geiger H, McLean R, Resnick J, Michael A, Good RA: The association of respiratory infection, recurrent hematuria, and focal glomerulonephritis with activation of the complement system in the cold. J Clin Invest 52:1698-1706, 1973

26. Hishitani Y, Inoi M, Kakehi K, Mozai T: Cold dependent activation of complement by mixed cryoglobulin. Bull Osaka Med School 28:83-92, 1982

27. Corvetta A, Spaeth PJ, Ghirelli PA, et al:: Complement activation and impaired capacity to solubilize immune complexes or to prevent their formation in essential mixed cryoglobulinemia. Diag Immunol 1:315-323, 1983

28. Digeon M, Laver M, Riza J, Bach JF: Detection of circulating immune complexes in human sera by simplified assays with polyethylene glycol. J Immunol Methods 16:165-183, 1977

29. Faaber P, van den Bersselaae LAM, van de Putte L, van den Berg WB: Circulating immune complexes and rheumatoid arthritis: the induction of complex formation between rheumatoid factor and IgG by polyethylene glycol. J Rheumat 16:1304-1309, 1989

30. Gronski P, Bodenbender L, Kanzy E-J, Seiler FR: C4binding protein prevents spontaneous cleavage of $\mathrm{C} 3$ in sera of patients with hereditary angioedema. Complement 5:1-12, 1988 